\title{
The Effects of Monomers Used in Polymeric Biomaterials on Renal Tissue
}

\author{
Efectos de los Monómeros de los Biomateriales Poliméricos Utilizados en Tejido Renal
}

\author{
Serpil Ünver Saraydın¹; Dursun Saraydın²; Zeynep Deniz Sahin Inan ${ }^{1}$ \& Berna Özdenoglu Kutlu ${ }^{1}$
}

SARAYDIN, S. Ü.; SARAYDIN, D.; SAHIN, I. Z. D. \& ÖZDENOGLU KUTLU, B. The effects of monomers used in polymeric biomaterials on renal tissue. Int. J. Morphol., 35(4):1203-1208, 2017.

SUMMARY: Biomaterials are mostly polymers and are used in artificial organ production in contemporary medicine. They are prepared by the polymerization reaction of many monomers. There are many monomers used in biomaterial production. In this study, we investigated whether acrylamide (AAm), methacrylamide (MAAm), N-isopropylacrylamide (NIPAm) and acrylic acid (AAc) used in polymeric biomaterial production had histopathological effects on renal tissue. In the present study, Wistar albino rats weighing 250-300 g were used. Following the intramuscular injections of $1 \mathrm{~mL}$ aqueous monomer solutions at $50 \mathrm{mg} / \mathrm{kg}$ concentrations, acrylamide group animals were sacrificed at $1^{\text {st }}, 2^{\text {nd }}$ and $3^{\text {rd }}$ weeks, the other monomer group animals were sacrificed at $1^{\text {st }}, 2^{\text {nd }}, 4^{\text {th }}$ and $6^{\text {th }}$ weeks. One $\mathrm{mL}$ serum physiologic were injected intramuscularly to the control group animals at the same time intervals with the experimental group animals. After histological follow-up, serial sections were prepared for evaluation under light microscope. In addition, the diameters of glomeruli and glomeruli space (Bowman's space) are measured, and the changes of the values of all groups with the exposure time were investigated. Acrylamide and its derivatives cause glomerular, arteriolar and tubule interstitial damage in the renal tissue. The narrowing glomeruli space, increasing diffuse mesangial matrix and tubular dilation was observed in some groups. In addition, dilatation, dissociation of tubular epithelium, thickening basement membranes and glycogenic vacuolization was also noted. These adverse results may be due to residual monomer. There should be no monomer residue in the polymer used as biomaterials.

KEY WORDS: Monomers; Polymeric biomaterials; Kidney.

\section{INTRODUCTION}

Biomaterials are mostly polymers and are used in artificial organ production in contemporary medicine. Biomaterials that similar to soft tissues are known as hydrogels (Saraydin et al., 2001). Hydrogels are cross linked polimer which could get swollen in water. They are prepared by the polymerization reaction of many monomers. Hydrogels were first used in contact lens production. Their mechanical stability, high oxygen permeability and its convenient diffraction index are reasons for their use in contact lens production. The other areas for hydrogel usage are artificial tendon production, as bioadhesives in wound repair, as artificial kidney membrane, artificial skin and biomaterial in plastic surgery. There are many monomers used in biomaterial production. In our previous studies, we investigated whether some monomers used in biomaterial production such as acrylamide, methacrylamide, $\mathrm{N}$-isopropylacrylamide, acrylic acid, 2-hydroxyethyl methacrylate, 1-vinyl-2- pyrrolidone and ethylene glycol had cytotoxic effects and induced apoptosis or not in spinal cord. Immunolocalization of glial fibrillary acidic protein (GFAP) was also determined, and was evaluated by using semi-quantitative morphometrical techniques. The cytotoxicity of monomers on cultured fibroblastic cell lines was also examined in vitro (Saraydin et al., 2001; Saraydın et al., 2011). Several studies on humans and on laboratory animals revealed neurotoxic effects as well as ataxi and muscle weakness caused by biomaterials. In addition, several epidemiological studies examining the relationship between dietary intake of acrylamide and cancers of the colon, rectum, kidney, bladder, and breast have been undertaken (Mucci \& Wilson, 2008). Histopathological effect of monomers was not sufficiently studied in renal tissue. Renal tubular cell apoptosis is a critical detrimental event that leads to chronic kidney injury in association with renal fibrosis (Dancer $e t$ al., 2010.; Sakaki et al., 2010; Vansthertem et al., 2010;

\footnotetext{
${ }^{1}$ Histology and Embryology Department, Medicine Faculty, Cumhuriyet University, 58140 Sivas, Turkey.

${ }^{2}$ Chemistry Department, Science Faculty, Cumhuriyet University, 58140 Sivas, Turkey.
} 
Chen \& Kuo et al., 2016). The present study was designed to investigate the role of galectin-3 (Gal-3), an important regulator of multiple apoptotic pathways. Galectin-3 (Gal3 ) is a $32-$ to $35-\mathrm{kDa}$ multifunctional lectin protein expressed by epithelial cells, endothelial cells, and macrophages that regulates numerous biological processes through interactions between carbohydrate recognition domain and via carbohydrate-independent mechanisms. Although it is predominantly located in the cytoplasm, Gal3 can be secreted extracellularly and it can also shuttle into the nucleus (Dumic et al., 2006; Henderson \& Sethi, 2009; Özdenoglu \& Saraydin, 2016). Intracellular Gal-3 is an important protein for cell survival due to its ability to block the intrinsic apoptotic pathway, while in the nucleus Gal-3 promotes cell proliferation-both via carbo- hydrateindependent mechanisms (Hsu \& Liu, 2004; NangiaMakker et al., 2007; Hsu et al., 2015).

In this study, we investigated whether acrylamide, methacrylamide, $\mathrm{N}$-isopropylacrylamide and acrylic acid used in polymeric biomaterial production had histopathological effects on renal tissue. To our knowledge, however, it has not been determined whether acrylamide and other monomers cause apoptosis in renal tissue. We therefore examined apoptosis by using terminal deoxynucleotydil transferase dUTP nick and labelling (TUNEL) method in renal tissue. Immunolocalization of Galectin-3 (Gal-3) was also determined. In addition, the diameters of glomeruli and glomeruli space are measured, and the changes of the values of all groups with the exposure time were investigated.

\section{MATERIAL AND METHOD}

Animals. An approval of the Experimental Animals Local Ethic Committee, Cumhuriyet University has been taken. In the present study, Wistar albino rats weighing 250-300 g (mean $270 \mathrm{~g}$ ) were used. Rats were fed ad libitum at standard laboratory conditions, and they were divided into control and experimental groups. Five animals per time interval were used in the present study.

Experimental Design. Following the intramuscular injections of $1 \mathrm{ml}$ aqueous monomer solutions at $50 \mathrm{mg} /$ $\mathrm{kg}$ concentrations, acrylamide group animals were sacrificed at $1^{\text {st }}, 2^{\text {nd }}$ and $3^{\text {rd }}$ weeks, methacrylamide, $\mathrm{N}$ isopropylacrylamid and acrylic acid group animals were sacrificed at $1^{\text {st }}, 2^{\text {nd }}, 4^{\text {th }}$ and $6^{\text {th }}$ weeks. One $\mathrm{ml}$ serum physiologic were injected intramusculary (i.m) to the control group animals at the same time intervals with the experimental group animals.
Histopathological study. The kidneys were removed, fixed in $10 \%$ buffered neutral formaldehyde and processed for light microscopicy. Four micrometer-thick sections were cut. All organ sections were processed and stained with Hematoxyline \& Eosin and PAS. Diameter of glomeruli and the glomeruli space were measured in the slides. In the hematoxylin and eosin (H\&E) stained sections, glomerular diameter $(\mathrm{x} 40)$, the glomeruli space (x100) were evaluated.

\section{Immunohistochemistry}

TUNEL. Apoptosis was evaluated by using terminal deoxynucleotydil transferase dUTP nick and labelling (TUNEL) method. In Situ Cell Death Detection Kit, POD (Roche, Germany) is used for apoptosis. Tumor sections were deparaffinized and dehydrated according to standard protocols. Tissue sections were incubated with Proteinase $\mathrm{K}$ working solution for $30 \mathrm{~min}$ at $21-37^{\circ} \mathrm{C}$. The slides were then washed with PBS ( $\mathrm{pH}$ 7.2-7.6) twice. Positive control was incubated with DNase I recombinant for $10 \mathrm{~min}$ at 15 $25^{\circ} \mathrm{C}$. Negative control was incubated with Label solution (without terminal transferase) instead of TUNEL reaction mixture. The slides were then washed with PBS (pH 7.27.6) three times. Converter-POD was added on slides and incubated in a humidified chamber for $30 \mathrm{~min}$ at $37^{\circ} \mathrm{C}$. The slides were then washed with PBS (pH 7.2-7.6) three times. DAB Substrate was added on slides and incubated for 10 $\min$ at $15-25^{\circ} \mathrm{C}$. The slides were then washed with PBS (pH 7.2-7.6) three times. The slides were mounted and analysed by fluorescence microscope (Olympus DP 70, Melville, NY, USA) (Figs. 3.D, 3.F).

Galectin-3. For immunohistochemical staining, the deparaffinized and dehydrated tissue sections were inactivated the endogenous peroxidase by an incubation with $3 \% \mathrm{H}_{2} \mathrm{O}_{2}$ for 10 minutes. To recover antigen, these sections were put into EDTA solution $(\mathrm{pH} 8.5)$ and heated in the microwave oven twice. The slides were then washed with PBS (pH 7.2-7.6) twice. Non-specific binding sites were blocked withUltra V Block (Scy Tec, USA) for 20 minutes. After the redundant liquid was discarded, the sections were incubated with primary antibody Galectin-3 (Scy Tec, USA) at room temperature for 1.5 hour and washed with PBS. Then the slides were incubated with biotinylated secondary antibody (Scy Tec, USA) for 20 minutes and washed with PBS, followed by incubation with streptavidin-HRP (Scy Tec, USA) for 20 minutes and washed with PBS. The antibody binding sites were visualized by incubation with a AEC kromogen (Scy Tec, USA) solution. The slides were counterstained for 1 minute with hematoxylin and then dehydrated with sequential ethanol for sealing and microscope observation. 


\section{RESULTS}

Acrylamide and its derivatives cause to damage glomerular, arteriolar and tubule interstitial area in the renal tissue (Fig. 1.A-H). Glomerular atrophy, widening of the glomeruli space and necrotic tubular epithelium (pyknotic nuclei and acidophilic cytoplasm) were observed in the first week after acrylamide, $\mathrm{N}$-isopropylacrylamide, methacrylamide and acrylic acid exposure (Figs. 1.A, 1.C, 1.E, 1.G). Increasing mesengial matrix, cellular degeneration and swelling of the tubular epithelium (star shaped tubular lumen) were determined second week after acrylamide exposure (Fig. 1.B). Thickening of the glomerular basement membrane and glycogenic vacuolization in the tubular epithelium were attracted attention in the $6^{\text {th }}$ week after methacrylamide exposure (Fig. 1.D). Glomerular lesion with increase of mesangial matrix in the glomerulus and glycogenic vacuolization in the tubular epithelium were identified in the $5^{\text {th }}$ week after $\mathrm{N}$-isopropylacrylamide exposure and as $6^{\text {th }}$ week after acrylic acid exposure (Fig. 1.F, 1.H).

The normal renal cortex contains glomeruli and tubules in the control group (Fig. 1.I).

Diameter of glomeruli and the glomeruli space were measured in the slides. Figures $2 \mathrm{~A}$ and $2 \mathrm{~B}$ show that the monomers were affected to the diameter of glomeruli and glomeruli spaces of all experiment groups until the end of work periods. It was observed that a decrease in the diameter
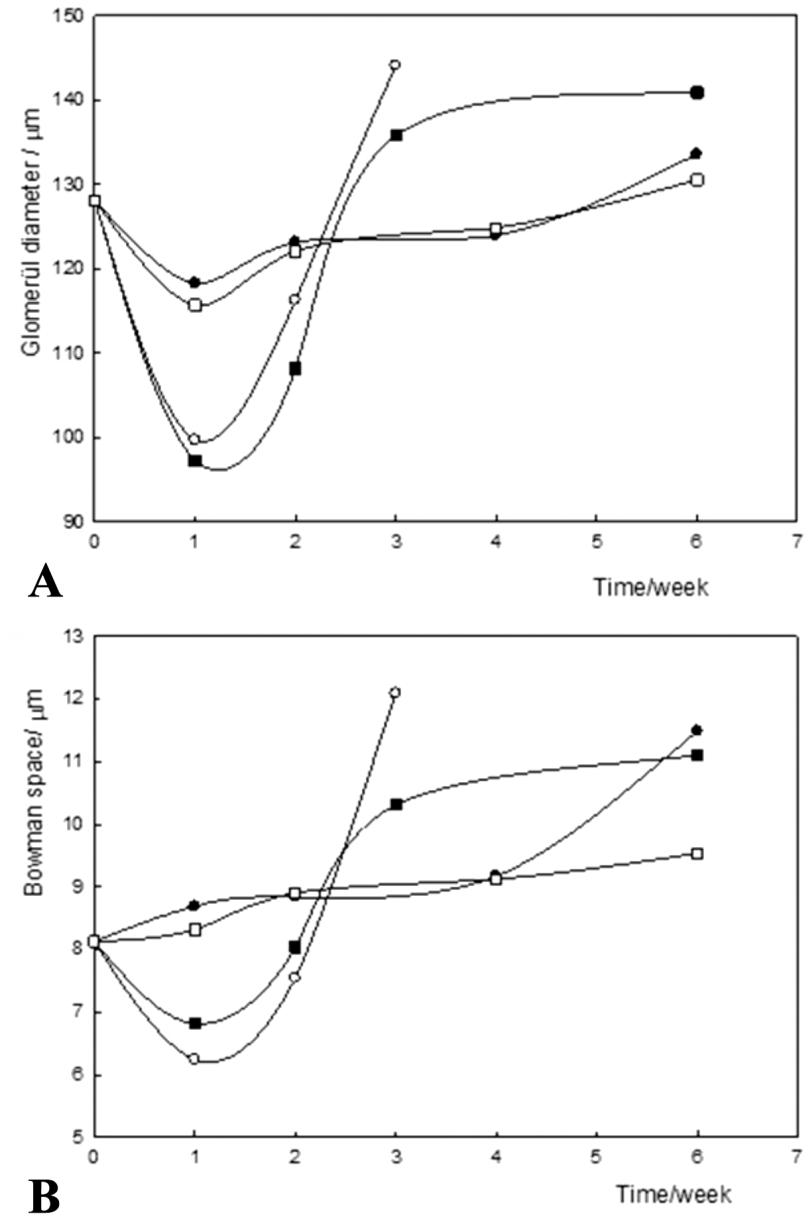

Fig. 2. A. Diameter of glomeruli vs time graphs. B. Glomeruli space vs time graphs.
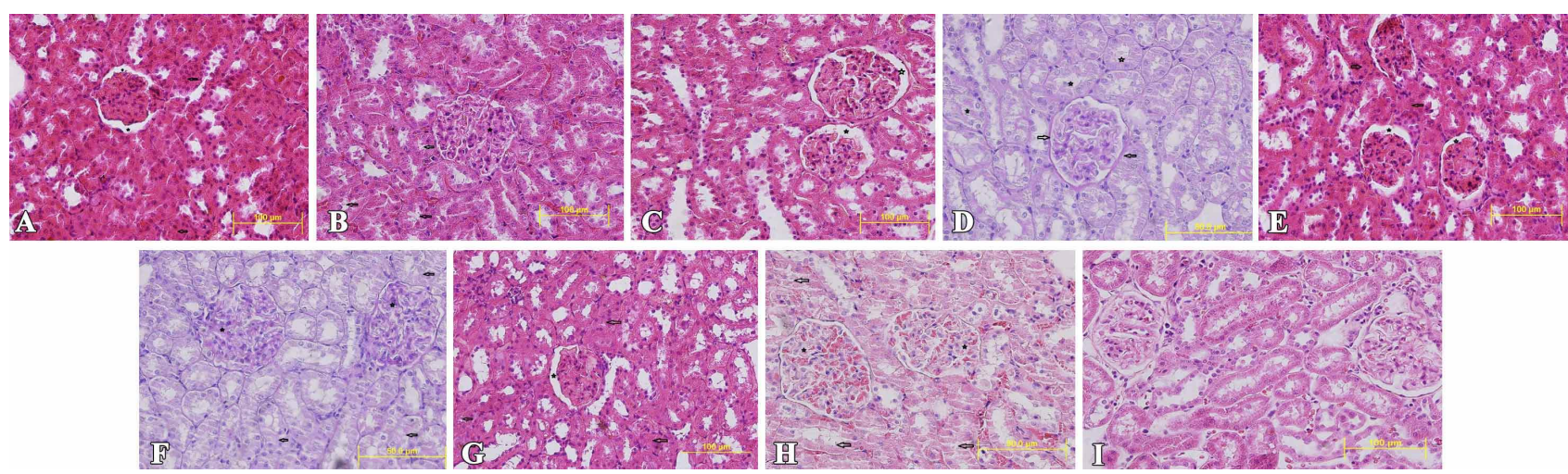

Fig. 1. A. Glomerular atrophy, widening of the glomeruli space and necrotic tubular epithelium (pyknotic nuclei and acidophilic cytoplasm) first week after acrylamide exposure. B. Increasing mesangial matrix and cellular degeneration and swelling of the tubular epithelium (star shaped tubular lumen) second week after acrylamide exposure. C. Widening of the glomeruli space first week after methacrylamide exposure. D. Thickening of the glomerular basement membrane and glycogenic vacuolization in the tubular epithelium $6^{\text {th }}$ week after methacrylamide exposure. E. Glomerular atrophy, widening of the glomeruli space and necrotic tubular epithelium (pyknotic nuclei and acidophilic cytoplasm) first week after $\mathrm{N}$-isopropylacrylamide exposure. F. Glomerular lesion with increase of mesangial matrix in the glomerulus and glycogenic vacuolization in the tubular epithelium $5^{\text {th }}$ week after $\mathrm{N}$-isopropylacrylamide exposure. G. Glomerular atrophy, widening of the glomeruli space and necrotic tubular epithelium (pyknotic nuclei and acidophilic cytoplasm) first week after acrylic acid exposure. H. Glomerular lesion with increase of mesangial matrix in the glomerulus and glycogenic vacuolization in the tubular epithelium $6^{\text {th }}$ week after acrylic acid exposure. I. The normal renal cortex contains glomeruli and tubules in the control group. 

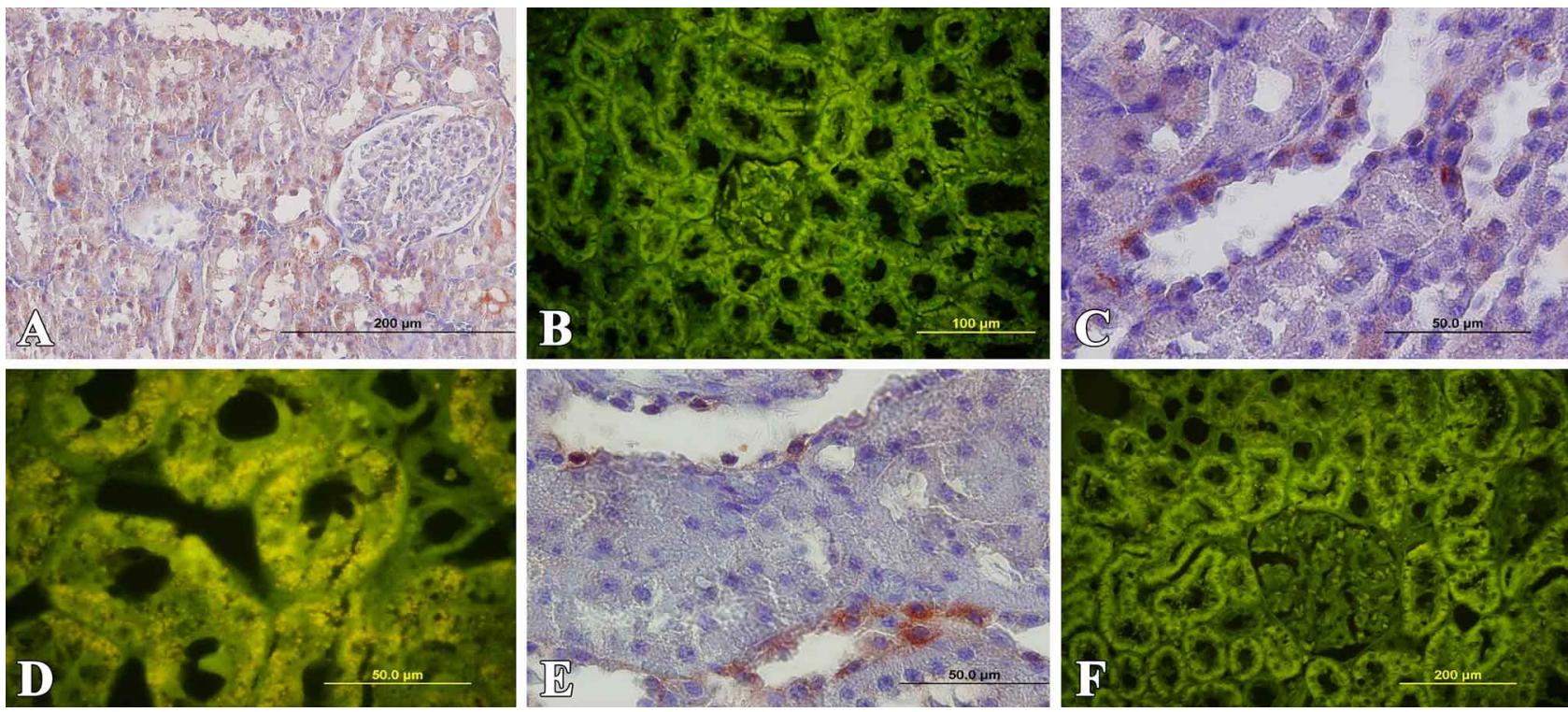

Fig. 3. A. Gal-3 expression in renal tubules of the control group. B. Few apoptotic cells in the control group. C. Gal-3 weak immunolocalization of tubules in the sixth week after acrylic acid exposure. D. TUNEL staining showed numerous apoptotic cells in the sixth week after acrylic acid exposure. E. Gal-3 weak immunolocalization of tubules in the first week after N-isopropylacrylamide exposure. F. TUNEL staining showed numerous apoptotic cells in the first week after $\mathrm{N}$-isopropylacrylamide exposure.

of glomeruli in first week, and an increase in the diameter of glomeruli in the following weeks. AAm and AAc monomers have affected the differentiation of the diameter of glomeruli more than NIPAm and MAAm monomers. The similar evaluation can be made for glomeruli spaces.

In normal kidneys, Gal-3 expression level is high according to experimental group (Fig. 2A). Renal Gal-3 expression was located in proximal and distal tubules (epithelial cells) but not in the glomeruli. A significant amount of apoptotic cells were found in experimental group. These cells were determined in proximal and distal tubules (epithelial cells). Only mild apoptosis was found in the controls (Figs. 3A, 3C, 3E).

\section{DISCUSSION}

Acrylamide and its derivatives are toxic, cancercausing (Hammad et al., 2013; Jamshidi \& Zahedi, 2015), industrial chemical used primarily in the preparation of polyacrylamide, which is used principally in water and wastewater treatment and in pulp and paper processing (Hammad et al.). Acrylamide and its derivatives are welldocumented neurotoxins in laboratory animals (Saraydin et al., 2011). Several epidemiological studies examining the relationship between dietary intake of acrylamide and cancers of the colon, rectum, kidney, bladder, and breast have been undertaken (Mucci \& Wilson).

The human kidney is a complex organ with approximately 1 million functional units called nephrons. The nephrons of two normal kidneys are collectively responsible for filtering approximately 150-180 liters of plasma per day and then processing the filtrate to regulate fluid, electrolyte and acid-base balance while eliminating waste products. The kidneys also produce hormones important for cardiovascular, hematologic and skeletal muscle homeostasis. The particular susceptibility of the kidney to drug toxicity can largely be attributed to its anatomy and function (McGavin \& Zachary, 2007; Bonventre et al., 2010).

The results of our present study clearly demonstrated that intramuscular injection of acrylamide and its derivatives to microscopic changes in the kidneys. Different forms of glomerulonephritis including bacterial, viral, chemical and immune-mediated glomerulonephritis have been identified so far. Chemically induced glomerular disease, although much less common than the immune mediated forms of glomerulonephritis, occurs in variety of different ways (LoPachin, 2004; Takenaka et al., 2004).

Kidney sections from the animals in group acrylamide and its derivatives, showed numerous histomorphological 
alterations that increasing mesangial matrix, cellular degeneration and swelling of the tubular epithelium glomerular hypercellularity, thickening of the glomerular basement membrane and glycogenic vacuolization in the tubular epithelium.

Diameter of glomeruli and the glomeruli space were measured in the slides. The monomers affected the diameter of glomeruli and glomeruli spaces of all experiment groups until the end of work periods. It was observed that a decrease in the diameter of glomeruli in first week, and an increase in the diameter of glomeruli in the following weeks. AAm and AAc monomers have affected the differentiation of the diameter of glomeruli more than NIPAm and MAAm monomers. The similar evaluation can be made for glomeruli spaces.

The molecular size (molar mass) of the monomers may have caused this differentiation. The small size monomers such as AAm (molar mass; $71.08 \mathrm{~g} \mathrm{~mol}^{-1}$ ) and AAc $\left(72.06 \mathrm{~g} \mathrm{~mol}^{-1}\right)$ can move rapidly and affect targets in a medium more than large size monomers such as MAAm (molar mass; $85.11 \mathrm{~g} \mathrm{~mol}^{-1}$ ) and NIPAm (113.16 g $\mathrm{mol}^{-1}$ ). On the other hand, the type of the side groups (such as carboxyl, hydroxyl, methyl, isopropyl, amide and amine) on the monomers can be affected varying on the diameters of glomeruli, for example: alkyl side groups were reduced less than the others.

Intracellular Gal-3 is primarily localized to the cytoplasm where it functions as an anti-apoptotic factor by inhibiting caspase activation similar to Bcl2 in the intrinsic pathway (Takenaka et al.; Khorsandi \& Orazizadeh, 2011). Apoptosis is an important physiologic process that ensures a balance between cellular proliferation and turnover in nearly all tissues. It was shown that Gal-3 had significant sequence similarity with Bcl-2, a well characterized suppressor of apoptosis, and human leukemia $\mathrm{T}$ cells transfected with Gal-3 cDNA displayed higher growth rates, indicating that Gal-3's antiapoptotic activity may occur via the cell death-inhibition pathway that involves Bcl-2 (Yang et al., 1996). In our study, Gal-3 expression level of control group is high according to experimental group. The results of the present study demonstrated that Gal-3 protects the kidney from progressive damage due to tubular apoptosis.

In conclusion, the present findings demonstrated kidney injury leading to glomerular lesion, thickening of the glomerular basement membrane and tubular cell swelling. All of caused adverse results should be toxicity of monomers. There should be no monomer residue in the polymer used as biomaterials.
SARAYDIN, S. Ü.; SARAYDIN, D.; SAHIN, I. Z. D. \& ÖZDENOGLU KUTLU, B. Efectos de los monómeros de los biomateriales poliméricos utilizados en tejido renal. Int. J. Morphol., 35(4):1203-1208, 2017.

RESUMEN: Los biomateriales en su mayoría son polímeros utilizados en la producción de órganos artificiales en la medicina contemporánea. Éstos son preparados mediante la reacción de polimerización de varios monómeros. Existe una gran cantidad de monómeros usados en la producción de biomateriales. En este estudio se investigó si la acrilamida (AAm), la metacrilamida (MAAm), la N-isopropilacrilamida (NIPAm) y el ácido acrílico (AAc) utilizados en la producción de biomateriales poliméricos tuvieron efectos histopatológicos en el tejido renal. En el presente estudio, se utilizaron ratas Wistar albinas que pesaban 250-300 g. Después de las inyecciones intramusculares $(1 \mathrm{ml})$ de soluciones acuosas de monómero a concentraciones de $50 \mathrm{mg} / \mathrm{kg}$, los animales del grupo de la acrilamida se sacrificaron a la $1^{\mathrm{a}}, 2^{\mathrm{a}}$ y $3^{\mathrm{a}}$ semanas, los otros animales del grupo monómero se sacrificaron a las $1^{\mathrm{a}}, 2^{\mathrm{a}}, 4^{\mathrm{a}}$ y $6^{\mathrm{a}}$ semanas. Se inyectaron intramuscularmente $1 \mathrm{ml} \mathrm{de}$ suero fisiológico a los animales del grupo control en los mismos intervalos de tiempo que los animales del grupo experimental. Después del análisis histológico, se prepararon secciones en serie para su evaluación bajo microscopio óptico. Además, se midieron los diámetros de los glomérulos y el espacio glomerular, y se investigaron los cambios de los valores de todos los grupos con el tiempo de exposición. La acrilamida y sus derivados causaron daño intersticial glomerular, arteriolar y tubular en el tejido renal. El estrechamiento del espacio de los glomérulos, el aumento de la matriz mesangial difusa y la dilatación tubular se observó en algunos grupos. Además, también se observó dilatación, disociación del epitelio tubular, membranas basales espesantes y vacuolización glicogénica. Estos resultados adversos pueden deberse al monómero residual. No debe haber residuo de monómero en el polímero utilizado como biomateriales.

PALABRAS CLAVE: Monómeros; Biomateriales poliméricos; Riñón.

\section{REFERENCES}

Bonventre, J. V; Vaidya, V. S.; Schmouder, R.; Feig, P. \& Dieterle, F. Nextgeneration biomarkers for detecting kidney toxicity. Nat. Biotechnol., 28(5):436-40, 2010.

Chen, S. C. \& Kuo, P. L. The role of galectin-3 in the kidneys. Int. J. Mol. Sci., 17(4):565, 2016.

Dancer, J. Y.; Truong, L. D.; Zhai, Q. \& Shen, S. S. Expression of Galectin3 in renal neoplasms: a diagnostic, possible prognostic marker. Arch. Pathol. Lab. Med., 134(1):90-4, 2010.

Dumic, J.; Dabelic, S. \& Flögel, M. Galectin-3: an open-ended story. Biochim. Biophys. Acta, 1760(4):616-35, 2006.

Hammad, A. Y.; Osman, M. E. \& Abdelgadir, W. S. Histopathological assessment and hematotoxicity of dietary acrylamide on Wistar rats. Int. J. Life Sci., 7(1):21-5, 2013.

Henderson, N. C. \& Sethi, T. The regulation of inflammation by galectin3. Immunol. Rev., 230(1):160-71, 2009.

Hsu, D. K. \& Liu, F. T. Regulation of cellular homeostasis by galectins. Glycoconj. J., 19(7-9):507-15, 2004. 
Hsu, D. K.; Yang, R. Y.; Saegusa, J. \& Liu, F. T. Analysis of the intracellular role of galectins in cell growth and apoptosis. Methods Mol. Biol., 1207:451-63, 2015.

Jamshidi, K. \& Zahedi, A. Acrylamide-induced acute nephrotoxicity in rats. Conference. In: ICASVM 2015: $17^{\text {th }}$ International Conference on Agronomic Sciences and Veterinary Medicine. Int. J. Anim. Vet. Sci., 2(4):169, 2015.

Khorsandi, L. \& Orazizadeh, M. Immunolocalization of galectin-3 in mouse testicular tissue. Iran. J. Basic Med. Sci., 14(4):349-53, 2011.

LoPachin, R. M. The changing view of acrylamide neurotoxicity. Neurotoxicology, 25(4):617-30, 2004.

McGavin, M. D. \& Zachary, J. F. Pathologic Basis of Veterinary Disease. $4^{\text {th }}$ ed. St. Louis, Mosby-Elsevier, 2007. pp.628-31.

Mucci, L. A. \& Wilson, K. M. Acrylamide intake through diet and human cancer risk. J. Agric. Food Chem., 56(15):6013-9, 2008.

Nangia-Makker, P.; Nakahara, S.; Hogan, V. \& Raz, A. Galectin-3 in apoptosis, a novel therapeutic target. J. Bioenerg. Biomembr., 39(1):7984, 2007.

Özdenoglu, B. \& Saraydin S. Ü. Does diabetes alter 1mmunolocalization of galectin-1 and galectin-3 in the rat ovary? Int. J. Morphol., 34(2):742$51,2016$.

Sakaki, M.; Fukumori, T.; Fukawa, T.; Elsamman, E.; Shiirevnyamba, A.; Nakatsuji, H. \& Kanayama, H. O. Clinical significance of Galectin-3 in clear cell renal cell carcinoma. J. Med. Invest., 57(1-2):152-7, 2010.

Saraydın, S. Ü. \& Saraydın, D. Histopathological Effect Characteristics of Various Biomaterials and Monomers Used in Polymeric Biomaterial Production in Biomaterials - Physics and Chemistry. Rosario Pignatello InTech, 2011.

Saraydın, S. Ü.; Bulut, H. E.; Özüm, Ü.; Inan, Z. D. S.; Polat, Z. A.; Yalman, Y. \& Saraydin, D. Evaluation of the cytotoxic effects of various monomers in vitro also their effects on apoptosis and GFAP immunolocalization in rat spinal cord in vivo. HealthMED, 5(1):17-28, 2011.

Saraydin, D.; Koptagel, E.; Ünver-Saraydin, S.; Karadag, E. \& Güven, O. In vivo biocompatibility of radiation induced acrylamide and acrylamide/ maleic acid hydrogels. J. Mater. Sci., 36(10):2473-81, 2001.

Takenaka, Y.; Fukumori, T.; Yoshii, T.; Oka, N.; Inohara, H.; Kim, H. R.; Bresalier, R. S. \& Raz, A. Nuclear export of phosphorylated galectin-3 regulates its antiapoptotic activity in response to chemotherapeutic drugs. Mol. Cell. Biol., 24(10):4395-406, 2004.

Vansthertem, D.; Cludts, S.; Nonclercq, D.; Gossiaux, A.; Saussez, S.; Legrand, A.; Gabius, H. J. \& Toubeau, G. Immunohistochemical localization of galectins- 1 and -3 and monitoring of tissue galectinbinding sites during tubular regeneration after renal ischemia reperfusion in the rat. Histol. Histopathol., 25(11):1417-29, 2010.

Yang, R. Y.; Hsu, D. K. \& Liu, F. T. Expression of galectin-3 modulates Tcell growth and apoptosis. Proc. Natl. Acad. Sci. U. S. A., 93(13):673742, 1996.

\author{
Corresponding author: \\ Serpil Ünver Saraydin \\ Cumhuriyet University, \\ Histology and Embryology Department \\ Medicine Faculty of Medicine \\ 58140 Sivas \\ TURKEY
}

E-mail:unversaraydin@gmail.com

Received: 12-12-2016

Accepted: 27-02-2017 